\title{
穊骨洞に達した眼窩内木片異物症例
}

\author{
横井 隆司 1 ) ・湯本 英二2）・黑木 悟3)
}

\section{Intraorbital Wooden Foreign Body Penetrating}

\author{
an Ethmoid Sinus
}

\author{
Takashi Yokoi and Satoru Kuroki \\ (Yoshida Municipal General Hospital) \\ Eiji Yumoto \\ (Ehime University)
}

\begin{abstract}
A 48-year-old man riding a motorcycle ran into a pine tree and suffered a small injury of the left medial lower eyelid. He consulted his family doctor and was told that his wound was too small to be sutured. The skin closed, but after a while a purulent discharge and fistula formation occurred at the same site. Three months after the injury he was referred to our hospital. Computed tomography revealed that an intraorbital foreign body had penetrated the ethmoid sinus. Under local anesthesia a left medial canthal incision was performed. The wooden foreign body, $4.5 \mathrm{~cm}$ long and $4 \mathrm{~mm}$ in diameter, was removed from the surrounding granulation tissue in the orbit. Two weeks later, a small wooden fragment was spontaneously extruded from the operative wound. In this case, the foreign body had not been found for a long time because it penetrated the posterior ethmoid sinus without any damage of the visual organs. No matter how small an eyelid injury is, one should be aware of the possibility of deeper damage and of persistent foreign bodies. In this case computed tomography was helpful in the diagnosis of the radiolucent wooden foreign body in the orbit and in the ethmoid sinus.
\end{abstract}

Key words: wooden foreign body, orbit, ethmoid sinus

はじめに

腿简内異物は，外傷が軽微である豩合患者自 身異物の侵入に気づかず診断が困難なととが多 い. 特に異物がX線透過性の木片, ガラス片で あると，見逃されやすい。近年，耳鼻咽堠科医

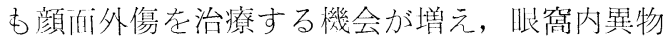

に対する注意が必要である、今回, 著者らが経 験した節骨洞に達した左眼窩内木片異物の 1 例 につき若十の文献的考然を加えて報告する。

\section{症例}

症例：48才男性.

初診：师和62年 4 月13日.

1) 町立吉田総合病院耳鼻咽喉科

2) 愛媛大学医学部耳鼻咽喉科学教室

3 ) 町立吉田総合病院眼科 
主訴：左下眼臉皮膚掼孔.

現病歴：昭和 62 年 1 月 23 日, 单車にて松の木 の生け垣に衝乫し，左下眼臉内側部に木の枝で 小さい傷を受けた。近医で消毒のみで一度は創 が閉鎖した。しかし次第に傷跡が腫脹し受傷 2 週後に排膿をみとめ, 同洔に黒いゴミが出てき た.この 1 週後にも同様に排膿して黒いゴミが 出てきた。近医外科にて切開排膿之同時に, 異 物の可能性を考元て創を開放したが異常を認め なかった。その後も皮膚瘦孔から排膿を繰り返 すため当院眼科より当科紹介された。

既往歴: 小学生の頃, 口蓋扁桃摘出. 22 才時 に虫垂切除. 毎年春先のアレルギー性鼻炎.

現 症

初診時, 両側下鼻甲介が貧血様で漿液性の鼻 漏を認め，両側鼻苜を伴亏慢性副鼻腔炎および アレルギー性鼻炎と診断した。左下眼瞼の内側 下部に皮膚瘦孔があり，その内側上方の腫脤部 を王迫すると瘦孔から排膿を認めた。また皮膚 瘦孔より涙管ゾンデを雨入すると内側やや上方 に向い約 $1 \mathrm{~cm}$ で骨様の屯のに当たり瘦孔は盲管
状であった。

眼科的には視力, 眼底, 結膜, 眼球運動等に 異常を認めなかった。沪囊造影では涙囊と皮膚 瘦孔の間に交通している所見は得られなかっ た。

副鼻腔単純 X線写真では両側篩骨洞に炎症性 のびまん性陰影を認めた（図 1 ）。副鼻腔断層 X線写真も両側前部篩骨洞から後部篩骨洞まで 炎症性のびまん性陰影を認めたが，異物の陰影 は認められなかった。 C T 検査では, 左眼窩下 縁内側部より左後部篩骨洞にかけて異物と思わ れる棒状の high density area 垫めた（図 2 ).

尚, 皮膚瘻孔よりの膿の塗抹培養とむ細菌を 認めなかった。

以上の所見加ら左眼窩内から後部穊骨洞に達 する異物を疑い, 当科入院の上, 手術を行っ た.

\section{手術所見㧍よび経過}

昭和 62 年 4 月 23 日，局所麻䣷下に，異物摘出 術を行った。まず内眼角部に瘦孔開口部を越え

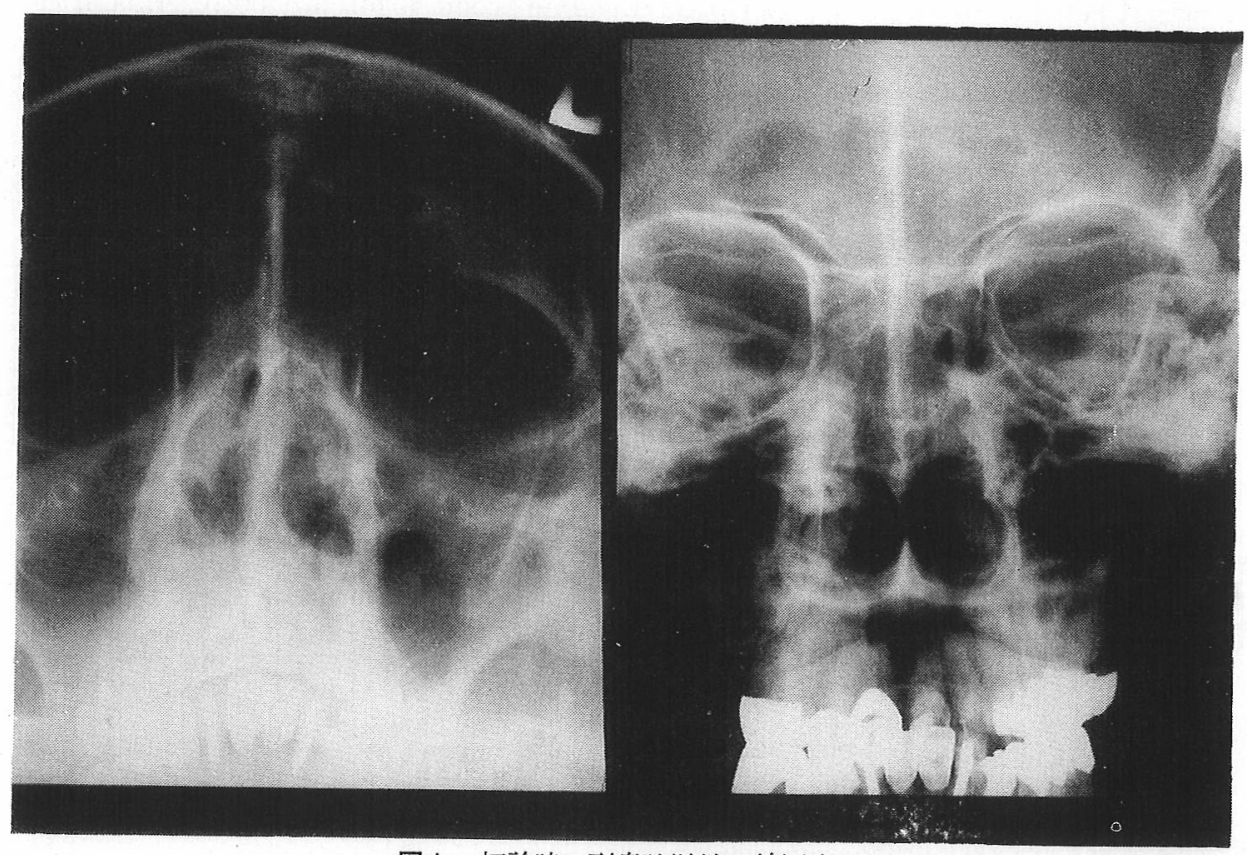

図１初診時の副鼻腔単純 X線写真 
るまで弓状の切開を加えた，次に眼蒚骨膜を紙 様板から剝離した。涙囊には損傷がなく, 紙様 板は前篩骨動脈まで骨欠損および骨膜下異物を 認めなかった。そこで瘻孔周囲の肉芽組織を除 去したところ，厚い洀痕組織の中に異物の前端 を認めた。この瘕痕を切開すると黒色の長い異 物が抵抗なく摘出された。異物は長さ $4.5 \mathrm{~cm}$, 直径約 $4 \mathrm{~mm}$ の小枝であった．乙の異物は下眼 瞼下部より涋囊の後方そして内直筋の下内側を 内上後方に刺さっていた（図３）。至して異物 は前箱骨動脈上り後おで紙様板を呀通して後部 篩骨洞に到達していたと考えられた。異物摘出 後，異物の存在していた瘦孔を抗生剂を含む生 食水で充分に洗浄した。乙の洗浄液はすべて鼻 腔側へ流出したため, 㿉孔は完全瘒孔と考えら れた。慢性副鼻腔炎は非活動的であったとと と, 瘦孔が洀痕組織でおおわれていたので, 鼻

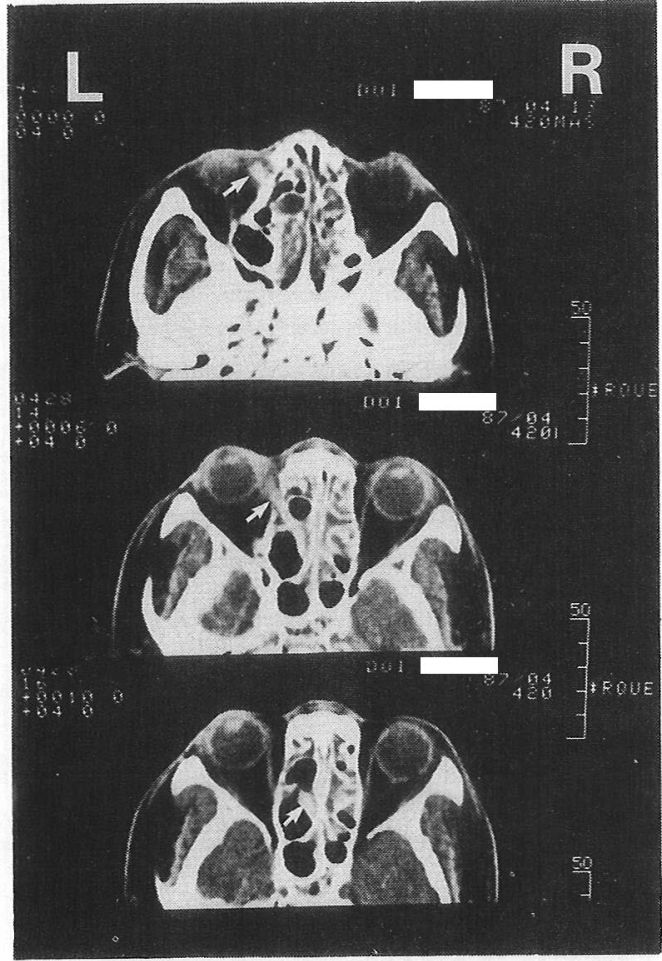

図 2 初湸時つC T像 上から順に $\mathrm{OM}$ 線上, $0 \mathrm{~mm}, 6 \mathrm{~mm}, 10 \mathrm{~mm}$ つレベル の断面. 矢印は異物による陰影を示す。
内鼻歨は二期的に除去することとして創を閉鎖 した。

ところが, 術後 5 日後より再び創部が腫脹し 始め, 術後 2 週後に $3,4 \mathrm{~mm}$ 大の木の皮が自然 に排出された（図 4)。その後，瘦孔は閉鎖し

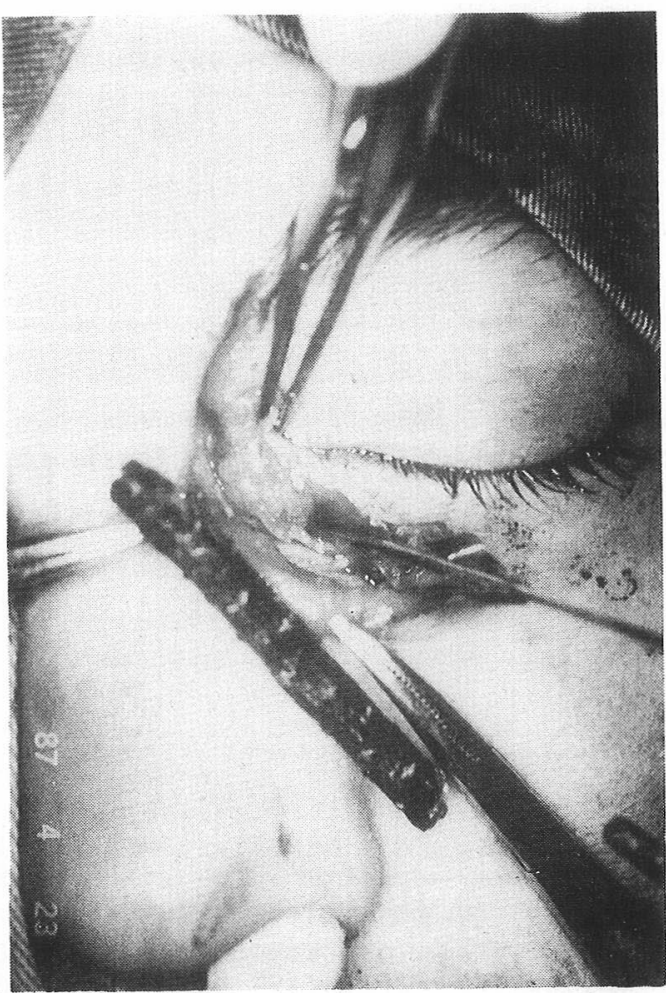

図 3 :術中写真

木片異物摘出直後の写真で, ゾンデの先が瘦孔部 であり，異物の刺入方向を示す.

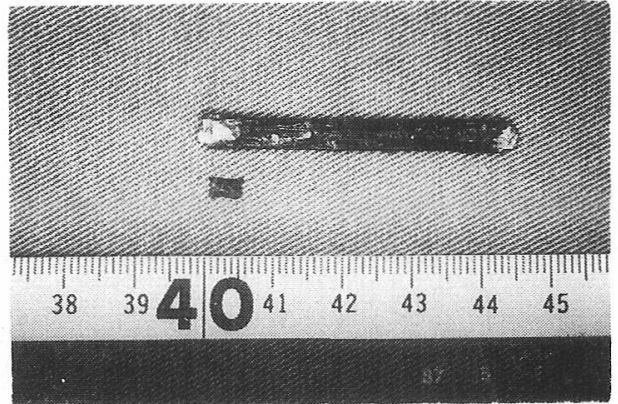

図 4 手術的に摘出した異物之術後自然 排出された異物。 
15力月の現在まで再発を綛めず順調に経過して いる.

\section{考按}

近年，耳鼻咽喉科医屯顔面の骨折や軟部組織 の外傷を治療する機会が多くなった。顔面の中 であ, とりわけ眼窩周囲は，皮膚の損傷が軽微 であっても眼简内あるいはより深部組織にまで の損傷や異物刺入の可能性があるととに留意

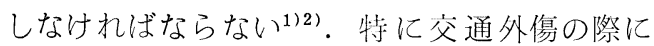
は，瞬将飞受傷することや，頭部外傷も受ける ことが多く，本人の知らないうちに顔面深部に まで異物が刺入しうる.

本例は左下眼瞼皮膚瘦孔を主訴として受傷 3 力月後に当科を受彰した。その間他院外科で切 開排膿を受けたにもかかわらず眼症状等がまっ たく久如していたために確定診断まで日時を要 した例である. 木片異物は径 $4 \mathrm{~mm}$ 長さ $4.5 \mathrm{~cm}$ 之 大きいものであったが，眼窩内の重要組織を損 傷する事なく後部穊骨洞にまで達していた。し かし, 過去の眼窩以異物あるいは眼望内を貫通 した穊骨洞異物の報告 ${ }^{2}$ 13) では, 失明, 眼球運 動障害等何らかの眼症状を来たしている場合が

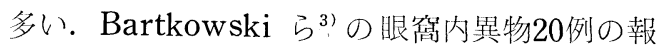
告では，13例に何らかの眼症状を認めている.

Wesley ら" の眼窩内木片異物 3 例ではすべて に眼症状があった。

松本ら ${ }^{5)}$ にると本邦での眼窩内異物は木片 が多いとしている，木片異物の場合，早期に感 染がおこり易く, 膿瘍や皮膚瘦孔が形成され る. 一方，銃弾異物のように高温高速で飛入す る無機物のものは炎症症状が軽度であること が多いとされ，42年間も放㯰された報告があ $3^{14)}$.

眼窝内異物の症状は，異物刺入時におこる外 傷性損傷と異物停留による疾患性損傷によるも のに分けて考えるてとができる，前者は即発性: 障害としてその損伤器官の症状が受傷直後に现 れる，後者は遅発性障夆として感染による膿 瘍, 㿉孔形成あるいは異物反応に上る肉芽形成 が起こる.また刺入する異物の種類, 少向, 位
惪，演留期間によって症状が修飾されるのはい うまでもない。木片異物が上眼瞼内側部より刺 入し上眼窩裂を通って中頭蓋窝へ貣通した例2)

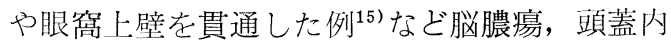
出血や髅膜炎の重篤な症状を呈した症例が報告 されている. 本例は涙囊, 眼球, 外眼筋, 視神 経を損傷するととなく，後部穊骨洞の方向に刺 入し，何らの合併症を屯惹起しなかった稀な例 と考えられた。

異物の刺入口は眼窝周囲のものが多く ${ }^{16)}$ ，な かでも浜田 ${ }^{17)}$ によると内眼的部が最も頻度が多 いとしている，本例の茎合も下眼瞼内眼伤部が 刺入口であった。

異物が刺入した場合，その刺入には非常に小 さく，短時間で閉鎖して外見上不明となる埸合 がある ${ }^{18)}$. 本例に抢いて眼窩内異物と診断しえ たのは, 繰り返す排膿を伴う瘻孔の存在に加 えて, C T 検査で異物と思われる棒状の high density area を認めたととによる. 本例のよ うなX線透過性の木片異物でも, その描出に C T検查が有用であった。

眼䆚刺創の新鮮外傷時には, 異物の有無を十 分探査する必要がある。たとえ見つけえない埸 合で屯受傷将の状況から異物の存在が疑われる 洔には㛜重に経過観察しなければならない。ま た本例のように複数の異物が存在する可能性も 念頭に置くべきである.

木片は感染頻度が高く疾患性摃傷を起てすた め眼䆚内木片異物の診断がついた際には早急に 手術にふみきる必要がある。しかし異物の種 類, 異物の存在する位圆之眼症状の有無によっ て治療法は異なる。浜田 ${ }^{17)}$ による, 小さなガ ラス片やプラスチックの異物で眼球, 眼窩の形 態的機能的異常のない場合は手術を直ちに行う 必要はないとしているままた眼窩尖端の銃弾異 物は保存的に経過をみる心゙きだとしている。ま た，症例により眼科，脳外科とのチーム医䝤が 必要なことは当然である。

\section{まとめ}

左下眼臉内側下部より刺入し左眼简および左 
後部節骨洞に認めた木片異物の1 例在報告し た。本例は眼症状なく左下眼瞼内側下部皮膚瘦 孔より繰り返す排膿を主訴として受診した。黑 物は受傷 3 力月後に摘出された.

顔面，特に眼臉部の外傷に際し，表面的には 小さい取るに足らない傷に見えて屯，本例のよ うに深い刺創による異物の存在を疑うことが重 要である。また深部組織まで刺入した木片異物 の診断にCT検査が有用であった。

本論文の要旨は第50回耳舅咽喉科臨床学会総会（昭 和63年 6 月24日）において発表した。稿を終えるに あたり, 御校閲を賜った愛媛大学医学部耳鼻咽喉科学 教室，丘村熙助教授に深謝いたします。

\section{参考文献}

1) Quayle AA : The significance of small wounds of the eyelids. Br J Oral Maxillofac Surg $24: 17 \sim 21,1986$.

2) Kazarian EL, Stokes NA and Flynn JT: The orbital puncture wound intracranial complications of a retained foreign body. J Pediatr Ophthalmol Strabismus 17:247〜 250, 1980.

3 ) Bartkowski SB, Kurek MK, Stypulkowska $\mathrm{J}$, et al: Foreign bodies in the orbit; review of 20 cases. J Max-Fac Surg 12:97 102, 1984 .

4) Wesley RE, Wahl JW, Loden JP, et al : Management of wooden foreign bodies in the orbit. South Med J $75: 924 \sim 932$, 1982.

5 ）松本雄二郎, 渋谷一穂, 武井一大, 他 : 眼球突出 を呈した眼窩内朴片異物の1例. 眼臨医報 78 ： 1161 1165, 1984.

6 ）㛫 弘吉, 早川美津子, 高橋 修, 他：眼窩内異 物の 1 例について. 埼玉医会誌 18:715〜716, 1983.
7) Weisman RA, Savino PJ, Schut L, et al : Computed tomography in penetrating wounds of the orbit with retained foreign bodies. Arch Otolaryngol 109:265 268, 1983.

8 ) 竹村 潔, 大西英之, 二階堂雄次, 他: 4 年後に 一側性眼球突出で発症した眼窩内異物の 1 治験 例. 脳外 $9: 1047 \sim 1051,1981$.

9）吉村陽子, 中島龍夫, 上敏明, 他 : 前頭洞 - 節 骨洞・脳内異物の 8 例. 臨外 $39: 1605 \sim 1610$, 1984.

10）佐藤俊一：直達性副鼻洞外傷つ 2 例（竹片及び木 片). 耳喉 $34: 669 \sim 672,1962$.

11）中原 学, 代田正道, 八尾和雄, 他：篩骨洞異物 の1例. 耷展 $26: 386 \sim 392,1983$.

12）矢原三十美, 内藤準哉, 石毛俊行, 他：外傷性副 鼻腔異物の 2 症例 (木片及び箸). 千葉医学 61: $279 \sim 282,1985$.

13）堤 昌已，武藤暢夫，武茂高行：眼窩および鼻副 兽腔の外傷性異物の 1 例. 耳展 $10: 59 \sim 61$, 1967.

14）長江大介, 新井寧子, 占内一郎, 他：副鼻腔求よ び眼窝における弾丸異物の 2 症例について. 耳喉 57 : 303 308, 1985.

15) Guthkelch AN : Apparently trivial wounds of the eyelids with intracranial damage. Brit Med J $2: 842 \sim 844,1960$.

16）藤田浩志，山本英一，稻坦下果夫，他：眼症状を 呈した篩骨洞木片異物の 1 症例. 耳喉 $58: 203$ $\sim 207,1986$.

17）浜田嶺次䬦：眼窝内異物. 眼科 Mook No.5 眼 の外傷 (深道義尚編)．110～119頁，金原出版， 東京, 1978.

18）谷内 修，松崎 浩：眼内異物および眼窩内異 物. 眼科 $25 ： 949 \sim 954,1983$.

$$
\begin{aligned}
& \text { 原稿採执：昭和 } 63 \text { 年 }: 9 \text { 月 } 2 \text { 日 } \\
& \text { 別刷請求先 : 横井隆司 } \\
& \text { T799-37 愛媛県北宇和郡吉田町北小路 } 217 \\
& \text { 町立吉田総合病院耳鼻咽㬋科 }
\end{aligned}
$$

